\title{
Little Ice Age and recent glacier advances in the Cordillera Darwin, Tierra del Fuego, Chile
}

\author{
Pequeña Edad de Hielo y los avances recientes en los \\ glaciares de la Cordillera Darwin, Tierra del Fuego, Chile
}

Johannes Koch ${ }^{1}$

\begin{abstract}
Preliminary fieldwork provides evidence for glacier advances in the Cordillera Darwin during the 'classic' Little Ice Age as well as in the late $20^{\text {th }}$ and the early $21^{\text {st }}$ centuries. Little Ice Age advances have been reported at nearby sites in the Patagonian Andes, but previous research claimed that glaciers of the Cordillera Darwin did not advance during 'classic' Little Ice Age time, but earlier. The present study indicates that glaciers in the Cordillera Darwin likely followed a similar Little Ice Age chronology as most glaciers in the Patagonian Andes. The recent glacier advances of over $1.5 \mathrm{~km}$ are supported by previous work. The reason for these advances remains unclear, especially as clear warming trends are observed in southern South America in the $20^{\text {th }}$ and early $21^{\text {st }}$ centuries. However, similarly to glaciers in Norway and New Zealand that also advanced late in the $20^{\text {th }}$ century, the strength of westerly atmospheric circulation has increased in Patagonia, which led to an increase in precipitation likely offsetting the increase in temperature.
\end{abstract}

\section{Keywords:}

Little Ice Age, recent glacier advances, Cordillera Darwin, southernmost South America.

\section{Resumen}

Trabajo preliminar de terreno proporciona evidencia de avances de glaciares en la Cordillera Darwin durante la clásica Pequeña Edad de Hielo, así como a finales del siglo 20 e inicios del 21. Los avances de la Pequeña Edad de Hielo han sido informados en sitios cercanos en los Andes Patagónicos, pero investigaciones previas postulan que los glaciares de la Cordillera Darwin no avanzaron durante la "clásica" Pequeña Edad del Hielo, sino que lo hicieron antes de ésta. El presente estudio indica que los glaciares en la Cordillera Darwin probablemente siguieron una cronología Pequeña Edad de Hielo similar a la mayoría de los glaciares en los Andes Patagónicos. Avances recientes de glaciares de sobre $1.5 \mathrm{~km}$ son respaldados por trabajos previos. Las razones para estos avances permanecen sin clarificar, especialmente ante las claras tendencias al calentamiento en el sur de Sud América en los siglos 20 e inicios del 21. Sin embargo, en forma similar a glaciares en Noruega y Nueva Zelandia que también avanzaron a finales del siglo 20, la intensidad de la circulación atmosférica del oeste ha aumentado en la Patagonia, lo que lleva a un incremento en precipitación muy probablemente compensando el aumento en temperatura.

\section{Palabras clave:}

Pequeña Edad de Hielo, avances glaciares recientes, Cordillera Darwin, extremo sur de Sud América.

\section{INTRODUCTION}

The Little Ice Age, which spans much of the past millennium, was a period of variable, but

\footnotetext{
1 Department of Geography, Kwantlen Polytechnic University, Surrey, British Columbia V3W 2M8, Canada. Joe.Koch@kpu.ca $\sum$
} 

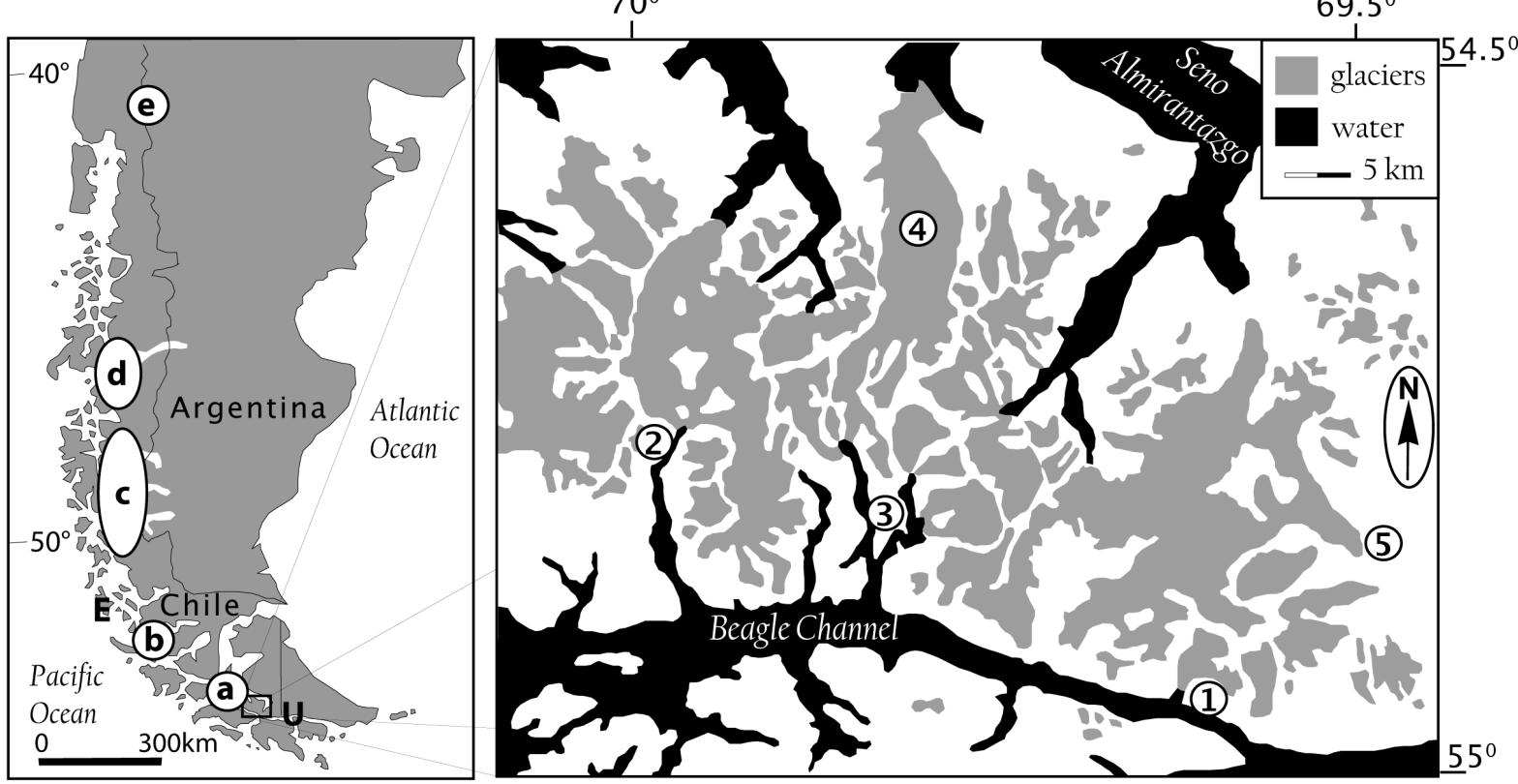

Fig. 1. Location map of Cordillera Darwin with location names mentioned in the text. 1, Glaciar Italia; 2, Seno Garibaldi with Ventisquero Garibaldi at the head of the fjord; 3, Bahia Pía with Glaciar Pía just east of the 3; 4, Ventisquero Marinelli; 5, Glaciar Stoppani. Inset map shows the location of Cordillera Darwin and other study and weather station sites mentioned in the text. a, Monte Sarmiento; b, Gran Campo Nevado; c, Hielo Patagonico Sur; d, Hielo Patagonico Norte; e, Monte Tronador, northern Patagonia; U, Ushuaia; E, Evangelistas.

generally cool climate when glaciers were more extensive than at other times in the Holocene (Grove, 1988). Evidence for this event is widespread and has been recorded in all glacierized mountains of the world (e.g., Luckman \& Villalba, 2001; Holzhauser et al. 2005; Koch et al. 2007). The Little Ice Age comprises early advances between AD 1100 and 1300 and a series of late advances from 1700 to 1900 (Grove, 1988). The latter were generally more extensive and commonly obliterated older deposits. In extratropical South America some glacier advances were more extensive during the $17^{\text {th }}$ century than during later advances (Villalba et al. 1990; Koch \& Kilian, 2005; Strelin et al. 2008; Masiokas et al. 2009b), but more data is needed to fully evaluate this situation. Available data suggest synchronous glacier behaviour during the Little Ice Age on a centennial timescale from Tierra del Fuego to Alaska (Luckman \& Villalba, 2001), but many glaciers have not been studied, and well-dated records of Little Ice Age glacier fluctuations are still needed (Luckman \& Villalba, 2001; Masiokas et al. 2009b). Very little previous research in Patagonia has concentrated on Little
Ice Age glacier fluctuations (Villalba et al. 1990; Winchester et al. 2001; Koch \& Kilian, 2005; Aravena, 2007; Masiokas et al. 2009a, b, 2010), even though the Patagonian Andes, with glaciers reaching well below treeline, show great promise for high quality data (Hall et al. 2011; Maurer et al. 2012).

Glacier fluctuations during the $20^{\text {th }}$ century have been documented from photographic and historical evidence, and detailed reconstructions are available for many glaciers around the world, most of which generally receded during the $20^{\text {th }}$ century (Dyurgerov \& Meier, 2000; Oerleman,s 2005), as did most in Patagonia (Warren \& Sugden, 1993; Warren, 1994; Holmlund \& Fuenzalida, 1995; Aniya, 1999; Rignot et al. 2003; Möller et al. 2007). Retreat dominated between the 1870s and about 1920. Stillstands and readvances occurred between 1920 and the 1960s, particularly in the 1930s and 1940s. Most glaciers in Patagonia have retreated since the $1960 \mathrm{~s}$, some at extraordinary rates. Exceptions to this general pattern include Perito Moreno Glacier, an eastern outlet glacier of the Southern Patagonian Icefield, which remains 
near its Neoglacial maximum (Warren, 1994; Minowa et al. 2015), and Glaciar Pio XI, a western outlet glacier of the Southern Patagonian Icefield that advanced over $11 \mathrm{~km}$ since 1944 and reached its maximum Holocene extent (Rivera et al. 1997) before it started to retreat sometime during the past decade (Koch, pers. obs in March 2006).

Glaciers in the Cordillera Darwin on Tierra del Fuego, southernmost Chile, have been studied in the past (Lliboutry, 1956; Holmlund \& Fuenzalida, 1995; Kuylenstierna et al. 1996; Porter \& Santana, 2003). Holmlund and Fuenzalida (1995) describe an asymmetric response of glaciers in the $20^{\text {th }}$ century between glaciers with accumulation areas facing south and west and the ones facing north and east; the latter showed retreat while the former advanced or had stable fronts. Kuylenstierna et al. (1996) documented late Holocene glacier fluctuations of the Bahia Pía area along the Beagle Channel (55 S; Fig. 1) and their data indicate that the glacier system reached maxima sometime prior to 3060 $\mathrm{BP}$, before $940 \mathrm{BP}$, and between 940 and 675 $\mathrm{BP}$, and that there was no 'classic' Little Ice Age (17 th to $19^{\text {th }}$ centuries) advance for this area.

The objectives of this paper are to a) provide preliminary evidence of 'classic' Little Ice Age as well as late $20^{\text {th }}$ and early $21^{\text {st }}$ centuries glacier advances in the Cordillera Darwin along the Beagle Channel; b) reconcile the findings of this study with Kuylenstierna et al. (1996); and c) explain the recent glacier activity.

\section{STUDY AREA AND METHODS}

The Cordillera Darwin (ca. 54.5 S, 68.5$71.5^{\circ} \mathrm{W}$ ), in the southwestern part of Tierra del Fuego, is the continuation of the Andes, which here trend west to east. The highest peak reaches nearly $2500 \mathrm{~m}$, and nearly $50 \%$ of the mountain range is glacierized (Holmlund \& Fuenzalida, 1995). In the southern part of the Cordillera, along the Beagle Channel, deep fiords dominate the landscape, and glaciers reach tidewater and calve (Fig. 1). Climate is humid and cool, with average annual temperature around $5^{\circ} \mathrm{C}$ and little annual variation (Núñez, 1994). Climate is dominated by strong westerlies and is highly oceanic on the west and south sides of the Cordillera but becomes in- creasingly continental towards the north and east. Precipitation is fairly equally distributed throughout the year, but decreases from about $7200 \mathrm{~mm}$ along the main divide of the Andes at Gran Campo Nevado (Schneider et al. 2003) to $500 \mathrm{~mm}$ at Ushuaia (Núñez, 1994). Vegetation is dominated by Magellanic Moorland and Magellanic Rainforest, which is dominated by Nothofagus betuloides and Nothofagus antarctica.

Preliminary fieldwork was conducted during a short visit to Glaciar Italia (Figs. 1,2) and by observing eight more glaciers from a vessel in March 2006. At Glaciar Italia ten trees were cored to provide dating control. Furthermore, a tree recently killed by a glacier advance was also cored. Due to lack of time at the glacier, and the rather dense forest cover on the outermost moraine it is likely that the oldest trees were not cored and thus ages provide a minimum estimate for moraine formation. Ecesis (the time from surface stabilization to seedling germination; Sigafoos and Hendricks, 1969; McCarthy \& Luckman, 1993; Koch, 2009), and the time for trees to grow to coring height (McCarthy et al. 1991; Koch, 2009) have not been investigated in this study, and thus values from other locations in Patagonia (Koch \& Kilian, 2005; Koch, 2009) are taken into account to provide better dating control on the moraine. Two cores from each tree were processed and analyzed following standard dendrochronological procedures (Stokes \& Smiley, 1996). A master chronology was developed for all samples to be able to crossdate the floating chronology of the killed tree and thus provide a calendar date of the most recent advance.

Ventisquero Garibaldi was advancing into forest and a tributary glacier during visits in 2004, 2006, and 2008. Masiokas et al. (2009b: Fig. 9) report this advance and mapped extents for 2000, 2001, 2002, 2003, and 2007. Frontal extents from 2000, 2001, 2004, 2006, 2008, and 2013 were mapped on an airphoto by comparing distinctive features close to the glacier margins and along the fiord coastline that could be identified on the air and ground photographs from each of these years. Differences in photo scale, contrast, lighting, and photographic distortion result in possible errors of up to $20 \mathrm{~m}$ in the mapped margins, but allow a general reconstruction of the amount and rate of this advance over time. 

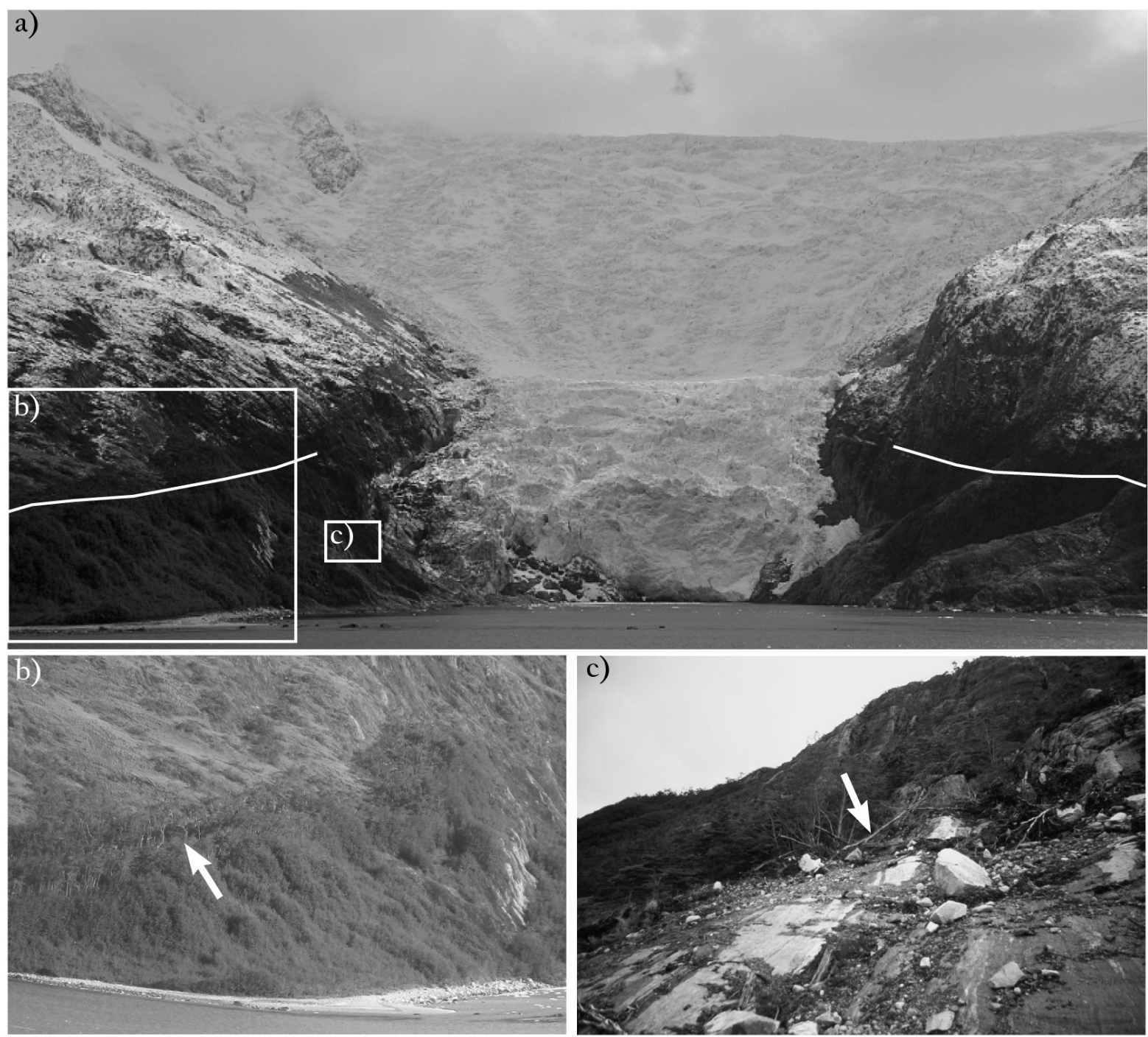

Fig. 2. (a) Photo of Glaciar Italia from the Beagle Channel looking north in December 2008. White lines are approximate extent of Little Ice Age advance indicated by a distinct break in vegetation. Locations of (b) and (c) are also indicated. (b) Distinct break in vegetation indicated by arrow. Similar vegetation breaks were observed at all other glaciers from the ground and on satellite photos. (c) Glaciar Italia advanced recently into forest killing and damaging trees as well as scraping off soil. Arrow indicates the tree that was sampled for dating.

\section{RESULTS}

Several glaciers on the southflank of Cordillera Darwin, along the Beagle Channel, were observed and a short amount of time was spent on shore at Glaciar Italia (Figs. 1, 2). Two distinct breaks in the forest vegetation are interpreted to represent an area not affected by glacier activity in the past few centuries and therefore outside the glacier forefield, a forest in a younger successional stage indicating ice cover within the past couple centuries, and an area that is still free of trees (Fig. $2 \mathrm{a}, \mathrm{b})$. No moraines were visible outside the glacier forefield, but subdued moraines are observed at the vegetation break from older to younger forest. The outermost and most distinct of these moraines can be traced across the mouth of the little embayment that separates it from the Beagle Channel. Two cores each were taken from eight trees growing on this moraine, which represents the maximum Little 
Ice Age advance, as well as from two trees that are growing in the older forest and thus outside the area covered by ice during the maximum Little Ice Age advance. The samples outside the forefield are interpreted to provide a maximum age for the outermost moraine, as these trees were not impacted by but were growing during the maximum Little Ice Age advance. The samples from the trees on the outermost moraine provide a minimum age for the maximum Little Ice Age advance. Samples from the trees outside the forefield yielded 257 and 288 rings, while trees on the outermost moraine ranged from 113 to 152 rings. Adding 15 years for ecesis and 5 years for growth to coring height provides AD1698 and AD1834 for the area just outside the forefield and the outermost moraine respectively. The ecesis value seems reasonable as previous studies suggest less than 20 years for Bahia Pía in the Cordillera Darwin (Holmlund \& Fuenzalida, 1995) and about 15 years for Glaciar Lengua at Gran Campo Nevado (Koch \& Kilian, 2005). Rings near the pith of all cores obtained were relatively narrow and thus slow growth to coring height is assumed (Koch, 2009). Values at Gran Campo Nevado varied from 2 to 7 years to reach $50 \mathrm{~cm}$ coring height (Koch \& Kilian, 2005), thus 5 years seems appropriate.

Glaciar Italia shows clear evidence for a recent advance into forest and over soil (Fig. 2c), which is supported by observations from other forefields in the Cordillera Darwin of advancing glaciers in the late $20^{\text {th }}$ century (Holmlund \& Fuenzalida, 1995; Porter \& Santana, 2003). The advance bulldozed into forest and killed and damaged trees. Bedrock is exposed from this advance on a bedrock knoll on the westside of the embayment, and the little soil that supported tree growth prior to this advance on the bedrock knoll is pushed into a small ridge that stands about 20 $\mathrm{cm}$ above the exposed bedrock. Trees that were growing on this bedrock knoll have been pushed ahead of the ice and into living trees beyond the reach of the advance. These pushed trees are tilted, some are nearly horizontal, rest against the living trees, and most of them lack any remaining foliage. Both Nothofagus species growing here are evergreen, and thus trees devoid of foliage were interpreted to be dead, while pushed trees that retained partial foliage were considered still

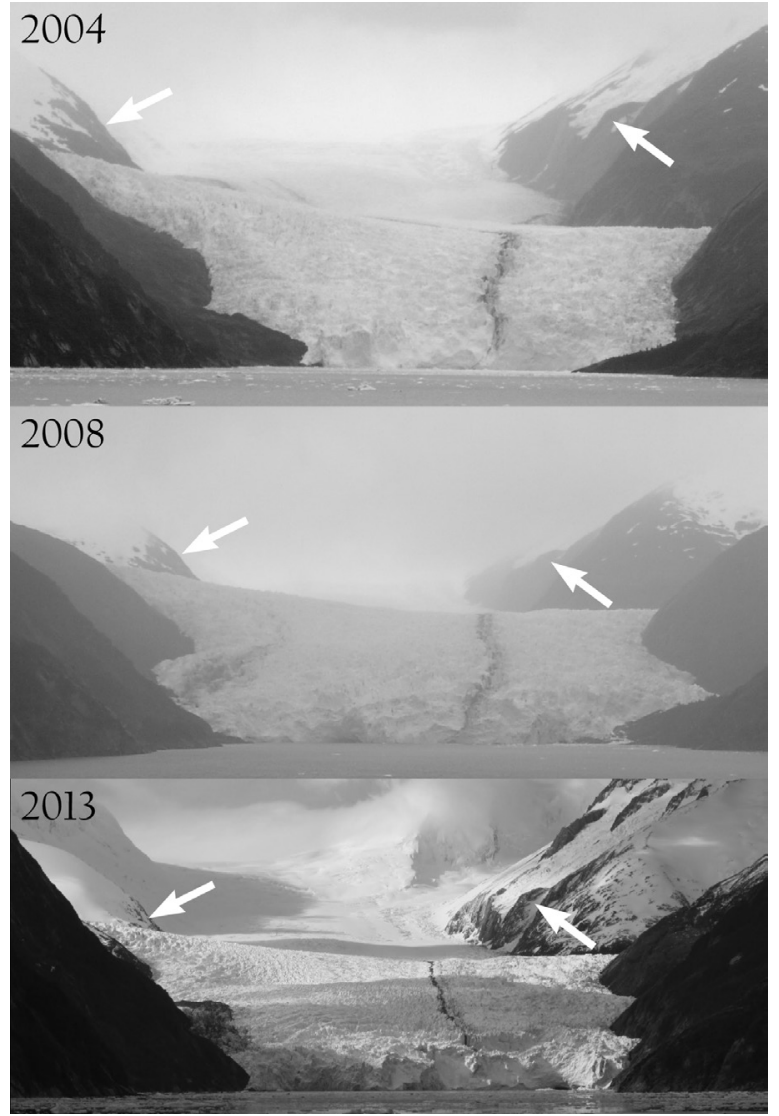

Fig. 3. Photo series documenting advance of Ventisquero Garibaldi between 2004 and 2013. Arrows point to the same locations in each photo.

alive. Two cores were taken from one of the trees with no foliage. The floating chronology, which spans 86 years, was crossdated with the living chronology $(r=0.517)$ and provides a kill date of 1999, indicating when this glacier advance ended. Since then Glaciar Italia has retreated by about $100 \mathrm{~m}$ and thinned by about $20 \mathrm{~m}$ and continues to retreat, as is the case for other glaciers on Tierra del Fuego (Holmlund \& Fuenzalida, 1995; Strelin \& Iturraspe, 2007). However, Ventisquero Garibaldi at the head of Seno Garibaldi (Figs. 1, 3) started its latest advance in 2001, which has continued at least until October 2013. Mapped extents in 2000, 2001, 2002, 2003, and 2007 (Masiokas et al. 2009b) are supplemented with extents in 2004, 2006, 2008, and 2013 (Fig. 3) to enable a reconstruction of the amount and rate of this advance (Table 1). Ventisquero Garibaldi, after retreating about $250 \mathrm{~m}$ between 2000 and 
Table 1. Amounts and rates of frontal change of Ventisquero Garibaldi since 2000.

\begin{tabular}{lccc}
\hline Period & Behaviour & Amount of change $(\mathrm{m})^{1}$ & Average rate of change $(\mathrm{m} / \mathrm{a})$ \\
\hline $2000-2001$ & retreat & $\sim 250$ & 250 \\
$2001-2004^{2}$ & advance & 400 & 133 \\
$2004-2006$ & advance & 500 & 250 \\
$2006-2008$ & advance & 250 & 125 \\
$2008-2013$ & advance & 580 & 116 \\
\hline
\end{tabular}

${ }^{1}$ Values are rounded to the nearest $10 \mathrm{~m}$.

${ }^{2}$ Glacier front behaviour between 2001 and 2004 was irregular with the western part of the tongue leading the advance in 2001-2002 and the eastern part catching up in 2002-2004.

2001, has advanced for over $1700 \mathrm{~m}$ between 2001 and 2013 at an average rate of $133 \mathrm{~m} / \mathrm{a}$ (Table 1). Between 2004 and 2006 this rate nearly doubled to $250 \mathrm{~m} / \mathrm{a}$, possibly due to it starting to coalesce with a smaller tributary glacier from the west.

\section{DISCUSSION AND CONCLUSIONS}

In this study evidence for 'classic' late Little Ice Age activity was observed at nine glaciers along the Beagle Channel on the southside of the Cordillera Darwin. Preliminary data from Glaciar Italia shows that its outermost moraine was deposited between AD1698 and AD1834, with the latter date considered a more accurate age. At each of the other observed glacier forefields similar evidence is visible in the form of distinct breaks in the forest cover, especially between the mature forest cover outside the moraines and the forest cover inside the glacier forefield. On air photos and satellite scenes of Cordillera Darwin similar landforms and vegetation breaks seem to be present for most glaciers including glaciers on the north, west, and east sides, indicating that glaciers of Cordillera Darwin advanced during the late Little Ice Age. Furthermore, evidence from Ventisquero Marinelli on the northside of Cordillera Darwin (Fig. 1) shows that glaciers overrode forests within the past 400 years (Hall et al. 2011), and a study of wood mats in the northeast lateral moraine of Glaciar Stoppani on the eastside of Cordillera Darwin (Fig. 1) provides clear evidence for its most extensive Holocene advance in the early $18^{\text {th }}$ century (Maurer et al. 2012).

These findings are in disagreement with a previous study in Bahia Pía on the Beagle Channel (Fig. 1) on the south flank of Cordillera Darwin (Kuylenstierna et al. 1996). The glacier system in Bahia Pía reached its maximum for the last time between $940 \pm 75{ }^{14} \mathrm{C}$ years BP (AD1020-1165) and $675 \pm 70{ }^{14} \mathrm{C}$ years BP (AD1270-1395), and by $250 \pm 70{ }^{14} \mathrm{C}$ years BP (AD1515-1805) the glacier system had retreated by more than 15 $\mathrm{km}$ (Kuylenstierna et al. 1996). Kuylenstierna et al. (1996) concluded that these data provide evidence that there was no glacial advance in Bahia Pía during the global Little Ice Age maximum (seventeenth to nineteenth centuries). This contrasts with the findings of more recent studies and needs explanation. Their evidence is based on radiocarbon dates obtained on peat and macrofossils from proximal and distal sites of a terminal moraine for the older dates and from wood on a peat-till interface for the $250 \pm 70{ }^{14} \mathrm{C}$ years BP date. The calibrated range of the $250 \mathrm{BP}$ date is AD15151805 (1 sigma) or AD1460-1820 (2 sigma), and for both sigma ranges there is a very low possibility, 0.062 and 0.081 respectively, that the date could be as young as AD1950. The potential problem with young radiocarbon dates is well known (Porter, 1981). This means the site could have been icefree as early as the late $15^{\text {th }}$ century, but it also could have been icefree only since the early $19^{\text {th }}$ century. Nonetheless, Kuylenstierna et al. (1996) use this age as evidence that the glaciers in Bahia Pía were not much more extensive during the global Little Ice Age maximum than at present. However, the site of the $250 \mathrm{BP}$ date is about $3.5 \mathrm{~km}$ from the present glacier snout. Even if the site was icefree at its earliest calibrated time, it is possible that the glacier reached well beyond the site, as the site is 
80-100 $\mathrm{m}$ above sea level, and thus the glacier could have thickened and advanced but stayed below the site. In both possible scenarios, that the $250 \mathrm{BP}$ site only became icefree in the early $19^{\text {th }}$ century or that it was icefree earlier, but the glacier reached farther down the fiord below the $250 \mathrm{BP}$ site, it seems reasonable to assume that the glacier in Bahia Pía was more extensive than at present during the global Little Ice Age maximum. Furthermore, distinct trimlines and several moraine ridges are visible on ground photos of Glaciar Pía on the east arm of Bahia Pía (Fig. 1), and two distinct partial moraine ridges protrude into Bahia Pía up to $7 \mathrm{~km}$ from the present glacier snout. The trimlines and moraines appear similar to the ones observed at Glaciar Italia, thus providing convincing evidence of glaciers in Bahia Pía advancing during Little Ice Age times.

Glaciers in Cordillera Darwin underwent late Little Ice Age advances, as did glaciers elsewhere in the Patagonian Andes, including Glaciar Ema at Monte Sarmiento, ca. $100 \mathrm{~km}$ to the west (Strelin et al. 2008), Glaciar Lengua at Gran Campo Nevado, ca. $300 \mathrm{~km}$ to the northwest (Koch \& Kilian, 2005), glaciers of the South and North Patagonian Icefields and their surroundings, ca. 600-1000 km to the north (e.g., Mercer, 1968, 1970; Marden \& Clapperton, 1995; Winchester et al. 2001; Masiokas et al. 2009a), and glaciers in northern Patagonia ca. $1600 \mathrm{~km}$ to the north (Villalba et al. 1990; Masiokas et al. 2010). The majority of these glaciers show rather synchronous behaviour with the culmination of Little Ice Age glacier advances occurring between AD 1600 and 1700 indicating a common forcing (Luckman \& Villalba, 2001; Koch \& Kilian, 2005). It seems likely that the Bahia Pía glacier system was more extensive early during the Little Ice Age (between $940 \pm 75{ }^{14} \mathrm{C}$ years BP [AD1020-1165] and $675 \pm 70{ }^{14} \mathrm{C}$ years BP [AD1270-1395]), than during the late Little Ice Age, which appears to be in agreement with other glaciers in the Patagonian Andes (Villalba et al. 1990; Koch \& Kilian, 2005; Strelin et al. 2008).

Some glaciers in the Cordillera Darwin were advancing in the late $20^{\text {th }}$ century (Holmlund \& Fuenzalida, 1995), and Glaciar Italia moved into forest and over soil at that time. Ventisquero Garibaldi started to advance in 2001 until at least
October 2013 for over $1.7 \mathrm{~km}$ (Fig. 3, Table 1 ). Why glaciers on the west and south flanks of Cordillera Darwin were advancing in the late $20^{\text {th }}$ century and some continue to do so, while glaciers on the north and east flanks have retreated significantly (Holmlund \& Fuenzalida, 1995; Porter \& Santana, 2003) is not fully understood. Instrumental temperature variations in southern Patagonia show clear warming trends in the $20^{\text {th }}$ century (Holmlund \& Fuenzalida, 1995; Rosenblüth et al. 1995, 1997; Villalba et al. 2003). Annual precipitation amounts decreased significantly in northwestern and central Patagonia (Rosenblüth et al. 1995; Aravena \& Luckman, 2009), and no clear trends are discernable in southern Patagonia nor in Ushuaia, the nearest weather station (Fig. 1; Holmlund \& Fuenzalida, 1995; Aravena \& Luckman, 2009). However, at Evangelistas (Fig. 1 ), the weather station most exposed to the strong westerlies, precipitation has increased almost threefold in the last two decades of the $20^{\text {th }}$ century (Aravena \& Luckman, 2009). Some of the glaciers that have remained stable or advanced are calving glaciers, and thus some authors argue that they might not record climatic conditions (Warren, 1993). However, the different pattern between the south and west flanks and the north and east flanks held true for land terminating glaciers in the late $20^{\text {th }}$ century, and thus it is more likely that the difference in glacier behaviour is driven by climatic changes (Holmlund \& Fuenzalida, 1995). Holmlund \& Fuenzalida (1995) show that glacier behaviour on the north and east flanks can be explained with observed changes in climate, but west and south facing glaciers should also show overall recession. They argue that increased wind activity could account for windward glaciers to advance due to increased orographic precipitation, and leeward glaciers to retreat significantly due to föhn winds, as observed at Ventisquero Marinelli (Fig. 1) between 1992 and 2000 (average retreat of $\sim 800$ m/a; Porter \& Santana, 2003). A southward shift of subtropical anticyclones displaces the cyclones towards the south, but at the same time strengthens the pressure gradient between the Hadley and polar cells, leading to higher wind activity and speeds (Holmlund \& Fuenzalida, 1995). Some glaciers in New Zealand and Norway also advanced at the end of the $20^{\text {th }}$ century (Chinn 
et al. 2005). In maritime Norway advances started as early as the mid-1960s, but were pronounced from the mid-1980s until around 2000. In New Zealand advances lasted from the mid-1980s to around 2000. Chinn et al. (2005) point out that what these two areas have in common is their location in maritime climates dominated by strong westerly airflow. They conclude that an increase in the strength of the westerly circulation and an associated increase in precipitation can explain the glacier advances in New Zealand and Norway. The Southern Annular Mode, a measure of zonal pressure gradient between $40^{\circ} \mathrm{S}$ and $60^{\circ} \mathrm{S}$, showed a positive trend between the mid-1960s to 2000 (Marshall et al. 2004), which implies an increase in strength or frequency of westerly winds at the latitude of the Cordillera Darwin. It thus appears that similar to glaciers in Norway and New Zealand, an increase of westerly airflow and an associated significant increase in precipitation apply to some maritime glaciers of the Cordillera Darwin, and that those conditions can offset increases in temperature, which could explain glacier behaviour on the windward side.

\section{ACKNOWLEDGEMENTS}

Polar Star Expeditions provided field access from their vessel M/V Polar Star.

\section{REFERENCES CITED}

Aniya, M. (1999). Recent glacier variations of the Hielos Patagónicos, South America, and their contribution to sea-level change. Arctic, Antarctic, and Alpine Research, 31, 165-173.

Aravena, J.C. (2007). Reconstructing climate variability in southern Chilean Andes. Unpublished $\mathrm{PhD}$ thesis, University of Western Ontario, London, Ontario, Canada.

Aravena, J.C. \& Luckman, B.H. (2009). Spatiotemporal rainfall patterns in southern South America. International Journal of Climatology, 29, 2106-2120.

Chinn, T., Winkler, S., Salinger, M.J. \& Haakensen, N. (2005). Recent glacier advances in Norway and New Zealand: A comparison of their glaciological and meteorological causes. Geografiska Annaler, 87A, 141157.

Dyurgerov, M.B. \& Meier, M.F. (2000). Twentieth century climate change: evidence from small glaciers. Proceedings of the National Academy of Sciences, 97,1406-1411.

Grove, J.M. (1988). The Little Ice Age. Methuen Press, London.

Hall, B., Porter, C. \& Denton, G. (2011). Holocene ice fluctuations at Ventisquero Marinelli, Cordillera Darwin, southern South America. XVIII. INQUA Congress 2011, Bern, Switzerland.

Holmlund, P. \& Fuenzalida, H. (1995). Anomalous glacier responses to $20^{\text {th }}$ century climatic changes in Darwin Cordillera, southern Chile. Journal of Glaciology, 41, 465-473.

Holzhauser, H., Magny, M. \& Zumbühl, H.J. (2005). Glacier and lake-level variations in west-central Europe over the last 3500 years. The Holocene, 15, 789-801.

Koch, J. (2009). Improving age estimates for late Holocene glacial landforms using dendrochronology - some examples from Garibaldi Provincial Park. Quaternary Geochronology, 4, 130-139.

Koch, J., Clague, J.J. \& Osborn, G. (2007). Glacier fluctuations during the last millennium in Garibaldi Provincial Park, southern Coast Mountains, British Columbia. Canadian Journal of Earth Sciences, 44, 12151233.

Koch, J. \& Kilian, R. (2005). Little Ice Age glacier fluctuations at Gran Campo Nevado, southernmost Chile. The Holocene, 15, 20-28.

Kuylenstierna, J.L., Rosqvist, G.C. \& Holmlund, P. (1996). Late-Holocene glacier variations in the Cordillera Darwin, Tierra del Fuego, Chile. The Holocene, 6, 353-358.

Lliboutry, L. (1956). Nieves and glaciares de Chile: fundamentos de glaciología. Ediciones de la Universidad de Chile, Santiago de Chile.

Luckman, B.H. \& Villalba, R. (2001). Assessing the synchroneity of glacier fluctuations in the western Cordillera of the Americas during the last millenium. In: V. Markgraf (Ed.) Interhemspheric Climate Linkages (pp. 119-140). Academic Press, New York. 
Marden, C.J. \& Clapperton, C.M. (1995). Fluctuations of the South Patagonian Icefield during the last glaciation and the Holocene. Journal of Quaternary Science, 10, 197-210.

Marshall, G.J., Stott, P.A., Turner, J., Connolley, W.M., King, J.C. \& Lachlan-Cope, T.A. (2004). Causes of exceptional atmospheric circulation changes in the Southern Hemisphere. Geophysical Research Letters, 31, L14205.

Masiokas, M.H., Luckman, B.H., Villalba, R., Delgado, S., Skvarca, P. \& Ripalta, A. (2009a). Little Ice Age fluctuations of small glaciers in the Monte Fitz Roy and Lago del Desierto areas, south Patagonian Andes, Argentina. Palaeogeography, Palaeoclimatology, Palaeoecology, 281, 351-362.

Masiokas, M.H., Rivera, A., Espizua, L.E., Villalba, R., Delgado, S., \& Aravena, J.C. (2009b). Glacier fluctuations in extratropical South America during the past 1000 years. Palaeogeography, Palaeoclimatology, Palaeoecology, 281, 242-268.

Masiokas, M.H., Luckman, B.H., Villalba, R., Ripalta, A. \& Rabassa, J. (2010). Little Ice Age fluctuations of Glaciar Rio Manso in the north Patagonian Andes of Argentina. Quaternary Research, 73, 96-106.

Maurer, M.K., Menounos, B., Clague, J.J. \& Osborn, G. (2012). Patagonian glacier advances in concert with those in western North America. AGU Fall Meeting 2012, San Francisco, CA, USA.

McCarthy, D.P., Luckman, B.H. \& Kelly, P.E. (1991). Sampling height-age error correction for spruce seedlings in glacial forefield, Canadian Cordillera. Arctic and Alpine Research, 23, 451-455.

McCarthy, D.P. \& Luckman, B.H. (1993). Estimating ecesis for tree-ring dating of moraines: A comparative study from the Canadian Cordillera. Arctic and Alpine Research, 25, 63-68.

Mercer, J.H. (1968). Variations of some Patagonian glaciers since the Late-Glacial. American Journal of Science, 266, 91-109.

Mercer, J.H. (1970). Variations of some Patagonian glaciers since the Late-Glacial: II. American Journal of Science, 269, 1-25.

Minowa, M., Sugiyama, S., Sakakibara, D. \& Sawagaki, T. (2015). Contrasting glacier variations of Glaciar Perito Moreno and Glacier Ameghino, Southern Patagonian Icefield. Annals of Glaciology, 56, 26-32.

Möller, M., Schneider, C. \& Kilian, R. (2007). Glacier change and climate forcing in recent decades at Gran Campo Nevado, southernmost Patagonia. Annals of Glaciology, 46, 136-144.

Núñez, S. (1994). El archipiélago de Tierra del Fuego. Technical report, Departmento de Climatología del Servicio Meteorológico Nacional. Buenos Aires.

Oerlemans, J. (2005). Extracting a climate signal from 169 glacier records. Science, 308, 675-677.

Porter, C. \& Santana, A. (2003). Rapid 20 th century retreat of Ventisquero Marinelli in the Cordillera Darwin Icefield. Anales del Instituto de la Patagonia, 31, 17-26.

Porter, S.C. (1981). Glaciological evidence of Holocene climatic change. In T.M. Wigley, M.J. Ingram \& G. Farmer (Eds.). Climate and History (pp. 82-110). Cambridge University Press, Cambridge.

Rignot, E., Rivera, A. \& Casassa, G. (2003). Contribution of the Patagonia Icefields of South America to sea level rise. Science, 302, 434-437.

Rosenblüth, B., Casassa, G. \& Fuenzalida, H. (1995). Recent climatic changes in western Patagonia. Bulletin of Glacier Research, 13, 127-132.

Rosenblüth, B., Fuenzalida, H.A. \& Aceituno, P. (1997). Recent temperature variations in southern South America. International Journal of Climatology, 17, 67-85.

Schneider, C., Glaser, M., Kilian, R., Santana, A., Butorovic, N. \& Casassa, G. (2003). Regional climate variations across the southern Andes at 53 S. Physical Geography, 24, 97-119.

Sigafoos, R.S. \& Hendricks, E.L. (1969). The time interval between stabilization of alpine glacial deposits and establishment of tree seedlings. U.S. Geological Survey Professional Paper, 650-B, 89-93. 
Stokes, M.A. \& Smiley, T.L. (1968). An Introduction to Tree-Ring Dating. The University of Arizona Press, Tucson.

Strelin, J. \& Iturraspe, R. (2007). Recent evolution and mass balance of Cordón Martial glaciers, Cordillera Fueguina Oriental. Global and Planetary Change, 59, 17-26

Strelin, J., Casassa, G., Rosqvist, G. \& Holmlund, P. (2008). Holocene glaciations in the Ema Glacier valley, Monte Sarmiento Massif, Tierra del Fuego. Palaeogeography, Palaeoclimatology, Palaeoecology, 260, 299-314.

Villalba, R., Leiva, J.C., Rubulis, S., Suarez, J. \& Lenzano, L. (1990). Climate, tree-ring, and glacial fluctuations in the Rio Frias valley, Rio Negro, Argentina. Arctic and Alpine Research, 22, 215-232.

Villalba, R., Lara, A., Boninsegna, J.A., Masiokas, M., Delgado, S., Aravena, J.C., Roig, F.A., Schmelter, A., Wolodarsky, A. \& Ripalta, A. (2003). Large-scale temperature changes across the southern Andes: 20 $0^{\text {th }}$ century variations in the context of the past 400 years. Climatic Change, 59, 177-232.

Warren, C.R. (1993). Rapid recent fluctuations of the calving San Rafael Glacier, Chilean Patagonia: climatic or non-climatic. Geografiska Annaler, 75A, 111-125.

Warren, C.R. (1994). Freshwater calving and anomalous glacier oscillations: recent behaviour of Moreno and Ameghino Glaciers, Patagonia. The Holocene, 4, 422429.

Warren, C.R. \& Sugden, D.E. (1993). The Patagonian Icefields: a glaciological review. Arctic and Alpine Research, 25, 316-331.

Winchester, V., Harrison, S. \& Warren, C.R. (2001). Recent retreat Glacier Nef, Chilean Patagonia, dated by lichenometry and dendrochronology. Arctic, Antarctic and Alpine Research, 33, 266-273. 